\title{
A LITTLE-KNOWN SCIENTIFIC CLUB IN HOBART, TASMANIA — ITS EARLY YEARS
}

\author{
by D. A. Ratkowsky
}

(with two tables)

\begin{abstract}
Ratkowsky, D.A. 2010 (30:xi): A little-known scientific club in Hobart, Tasmania - its early years. Papers and Proceedings of the Royal Society of Tasmania 144: 37-42. https://doi.org/10.26749/rstpp.144.37 ISSN 0080-4703. School of Agricultural Science, University of Tasmania, Private Bag 54, Hobart, Tasmania 7001, Australia. Email: D.Ratkowsky@utas.edu.au
\end{abstract}

A history of the early years (1935-1939) of the Biological Club in Hobart, Tasmania, is presented, describing briefly the ticles and content of some of the talks given in those formative years. The genesis of the Club is put into the broader context of the development of science in Tasmania during that period. The question of why women were not included in the membership in the Club at that time is explored. Key Words: Tasmanian Biological Survey, foundation members, women members, Hobart, Tasmania, Biological Club.

\section{INTRODUCTION}

A meeting was held on 6 June 1935 at the house of Dr W.L. Crowther (later Sir William Crowther) to discuss a proposal that a Biological Club be formed in Hobart. In addition to Dr Crowther, W.M. Carne, V.V. Hickman, D. Martin and J.W. Evans were present at that meeting. The ground rules for the Club were set up, most of which are still in existence. Summarised briefly, the rules provided for informal monthly meetings on the third Monday of the month during April-November, later changed to March-November, held at members' homes and chaired by the member at whose home the meeting was held. The papers delivered were to be connected in some way with one of the biological sciences and it was considered desirable that only papers be presented that were of general interest, or were on subjects capable of being rendered intelligible to a majority of the members, with topics that promoted subsequent discussion being preferred. In addition to papers dealing with the special interest of any one member, subjects could be chosen of wide and general interest, for which one member was asked to gain familiarity, for the purpose of subsequently delivering a paper on the chosen topic. Distinguished scientists visiting Hobart could be invited to attend any meeting, and the host of the evening was permitted to introduce one or two guests. Hospitality provided at meetings was to be of the simplest nature.

Minutes were not kept until 1944. Earlier records were reconstructed from such notice papers as had been preserved, and from members' personal records compiled by H.D. Gordon, Honorary Secretary from 1944 to 1947 , and drawing upon the memory of other early members, particularly T.D. Raphael. This reconstructed "Minute Book" is now housed in the University of Tasmania's Morris Miller Library, Special and Rare Materials Collection, and covers the period between the formation of the Club and the end of 1959. The titles and synopses of the talks mentioned here were obtained from this book.

\section{EARLIEST MEETINGS, 1935-1937}

The first general meeting of the Club (as distinct from the inaugural meeting held on 6 June 1935 to discuss the formation of the Club) took place on Monday, 15 July 1935. W.M. Carne gave a talk on "Causes of breakdown in
Tasmanian apples". Walter Carne was a foundation member of the Club and had a significant interest in it, but he left for the United Kingdom in 1936 to observe and report upon the condition at arrival of fruit shipments there, as Tasmania at that time was Australia's leading exporting state for apples and pears (Martin 2004). Upon returning, he was stationed in Melbourne, but still maintained some contact with operations in Tasmania and attended the occasional Biological Club meeting when a visit to Hobart coincided with the Club's meeting date. Carne's assistant from the beginning of 1933 until his departure from Tasmania was D. Martin, later to succeed him as leader of the project on the problems associated with the apple storage disorder, bitter pit (Martin 2004)

The second general meeting of the Club (19 August 1935) was the occasion for a talk by Dr W.L. Crowther entitled "Migrations of the Tasmanian Race". Crowther, who received a knighthood in 1955 , was a prominent medical practitioner and surgeon, a fourth-generation Tasmanian whose great-grandfather Dr William Crowther had arrived in Tasmania in 1825. His grandfather was also a medical practitioner and had achieved notoriety in the less-enlightened times of 1869 when he "mutilated the body of an Aborigine, William Lanney" (see von Oppeln 2006). The younger Crowther not only became distinguished as a general and obstetrics practitioner in Hobart, he was also keen on natural history from boyhood and was active in the Tasmanian Field Naturalists' Club, serving as its President (1924-1928; Fenton 2004). He was also active in the Royal Australasian Ornithologists Union as well as a member of The Royal Society of Tasmania from 1911 and a Royal Society of Tasmania Council member between 1919 and 1958. He was also a long-term trustee (1919-1973) of the Tasmanian Museum and Art Gallery and a passionate collector, bibliophile and anthropologist (von Oppeln 2006). Of relevance here was his regard for the welfare of the Australian Aboriginal peoples, urging compassion and respect and a national approach to their welfare, and warning of the tragedy that would ensue if they succumbed to the same fare as that which had befallen their Tasmanian counterparts (see von Oppeln 2006). Crowther was sincere about his interest in Aboriginal welfare and his talk in 1935 was one of many he gave over the years on Aboriginal subjects. That his interests were widespread is evidenced by another of his talks, entitled "The Tasmanian guano industry". 
The third general meeting of the Club (16 September 1935) heard an address by V.V. Hickman on "Trap-door spiders". Vernon Hickman was an invertebrate zoologist who was Lecturer in Biology at the University of Tasmania from 1932 and Professor of Biology from 1943 to 1959. He had a specific interest in spiders, but his many talks to the Biological Club over the years included one on the freshwater Crustacea of Tasmania and another on ecdysis, the shedding of an outer integument or layer of skin, as in insects, crustaceans and snakes. Hickman was elected a fellow of the Royal Entomological Society of London in 1947 and he won a prestigious medal of the Royal Physiographical Society of Lund, Sweden, in 1951, but he never travelled overseas to meet other scientists, remaining a modest man who rarely talked about his work or achievements (Guiler 2006).

It is unclear whether a general meeting occurred in October 1935 , no permanent record existing, but the last meeting during the Club's first year took place on 18 November, with J.W. Evans talking on "Biological races in insects". John Evans was an entomologist, born in India but educated at Cambridge University in England, who worked at the Tasmanian Department of Agriculture from 1935 to 1944. Evans can be said to be the prime mover for the creation of the Biological Club, being present at the meeting of 6 June 1935 in which it was agreed that the Club should be created. He served as its Honorary Secretary until the end of 1943, when he resigned in preparation for his taking up of a position at the Imperial Institute of Entomology, London. He was later to return to Australia to become Director of the Australian Museum in Sydney, 1955-1966 (McCarthy 2004).

The first general meeting of 1936 (16 March) heard a talk by E.E. Unwin entitled "Respiratory methods of Isopods". Ernest Unwin came to Tasmania from England where he had been, inter alia, a staff member in the biology department at the University of Leeds, to become Headmaster of The Friends School in Hobart (Oats 2006). As was the case with many of the members of the Biological Club, his interests were broad and extended outside of the confines of his employment or profession. He was one of the founders of the Hobart Repertory Theatre Society, a vice-patron of the Art Society, and involved in service organisations such as the Rotary Club and Toc H (Anon. 1944).

The general meeting of 20 April 1936 was the occasion of a talk by Prof. A.L. McAulay on "Life in a fourdimensional world". Leicester McAulay was the son of Alexander McAulay, Foundation Professor of Mathematics and Physics from 1896 to 1927, the University of Tasmania having been created in 1890 , ten years before Australian Federation, as the fourth university established in Australia. The younger McAulay himself became Foundation Professor of Physics in 1927, when the Department of Mathematics and Physics was split into separate departments (Scott 2006). The fact that physicists were attracted to a Biological Club reflects that many scientists in that period were "polymath". McAulay's membership and activity in the Biological Club was not an isolated instance. For example, the physicist A.G. Fenton was not only a member of the Club for 53 years, he later became its Honorary Secretary and retained that position until the end of 2007 , shortly before his death. Prof. S.W. Carey and Dr M.R. Banks, the latter having joined in 1950 and still a member after 60 years, are other examples of "non-biologist" members of the Club. Carey and Banks both had strong paleontological interests; hence, although geologists by definition, they crossed the interface with biology (M.R. Banks pers. comm.).

The general meeting of 18 May 1936 heard A.N. Lewis speak on "Ecology of the Derwent Estuary". Arndell Lewis pursued law as a career and was admitted as a solicitor to the Supreme Court in 1922. He was also a member of a family law firm, his father Sir Neil Lewis having been a lawyer as well, and was acting Professor of Law at the University of Tasmania in 1925 and 1930 . Because Lewis had an intense interest in natural history and in geology, he joined the Tasmanian Field Naturalists' Club while still at school and was elected to its Committee in 1913, later becoming its President. He published 18 papers in the Papers and Proceedings of the Royal Society of Tasmania between 1921 and 1939, making enduring contributions to the geology of Tasmania. He was Lecturer in Geology at the University of Tasmania from 1927 to 1931 and is another example of a "non-biologist" member of the Biological Club. Lewis also pursued a political career, and was elected to the House of Assembly in 1932 as a member for Denison (Anon. 2010).

The general meeting of 15 June 1936 featured a talk by Dr J. Pearson entitled "Sex", covering such questions as sex determination, sex-linked inheritance, intersexes, gynandromorphs (organisms having both male and female characteristics), sex reversals and parthenogenesis. Joseph Pearson came to Tasmania in 1934 to take up the position of Director of the Tasmanian Museum and Art Gallery following the sudden death of Clive Lord from a stroke, which left the position vacant. Pearson was a distinguished zoologist, having retired from the post of Director of the Colombo Museum and Marine Biologist to the Ceylon Government, a position he held for 24 years. He was enthusiastic about the need for dialogue amongst biologists, and foresaw that a Biological Club would provide that platform. Pearson was a frequent speaker at Biological Club meetings until his retirement in 1952, as recorded in the reconstructed "Minute Book" referred to earlier.

The next meeting of the Club, thought to have been held on 20 July 1936 (date uncertain), was the occasion for a talk by R.G. Brett on "Hybrids, from simple Mendelian monohybrids to interspecific hybrids". Gordon Brett; born in Launceston and educated in the north of Tasmania, became a school teacher in mathematics and physics, and eventually achieved the position of Superintendent of High Schools in Tasmania, based in Hobart, reaching retirement in that position. He was a keen field naturalist, who had a particular interest in eucalypts (Potts \& Reid 2003), being particularly adept at recognising hybridisation of Eucalyptus in the wild. His publications include the original description of the very rare species Eucalyptus morrisbyi, and he documented many eucalypt hybrids for the first time.

The following meeting, thought to have been held on 17 August 1936 (date uncertain), heard a talk by D. Martin on "Respiration of apples". As already mentioned, Don Martin was the assistant to W.M. Carne, eventually becoming leader of the project after Carne's trip to England and the latter's subsequent change of job and residence. Research into postharvest storage disorders of apple fruits occupied a large part of Martin's career, and despite the decline in importance of the apple industry, still remains a major consideration wherever Tasmanian apples are exported. After the end of the Second World War, when the Executive of CSIR (later CSIRO) decided to set up a Tasmanian Regional Laboratory, Martin was appointed Officer-in-Charge (1948). Martin was a Biological Club stalwart, continuing his membership until 
his death on 28 December 2008, a remarkable 73 years. Although eucalypt hybridisation had been observed in the wild, as noted in the previous paragraph, it remained to Martin to produce the first eucalypt hybrid artificially, by crossing $E$. urnigera pollen obtained from the upper slopes of $\mathrm{Mt}$ Wellington with $E$. globulus from The Domain (D. Martin pers. comm.).

T.D. Raphael addressed the general meeting held on 21 September 1936, his topic being "Pollination problems in fruit". A counterpart to D. Martin of CSIRO, Tom Raphael worked for the Tasmanian Department of Agriculture, and, unsurprisingly, due to the importance of the apple industry to Tasmania, research into horticultural problems was carried out both in the national research body (CSIRO) and at the state level. In 1936, Australia exported 4703000 boxes of apples to Europe $(89 \%$ of which went to the United Kingdom). Of this total, Tasmania's share was 2738000 boxes $(58.2 \%)$, the nearest competitors being Western Australia (17.4\%), Victoria (13.0\%) and South Australia (9.4\%) (see Anon. 1937).

At the meeting believed to have taken place on 19 October 1936, C.G. Stephens talked on "The significance of the phosphate status of Tasmanian soils". An accomplished pedologist, Charles Stephens was the author of several small books on various aspects of Tasmanian soils, including The Soils of Tasmania, The Basaltic Soils of Northern Tasmania, The Apple Growing Soils of Tasmania, and one on King Island soils. As part of the CSIR Division of Soils, Stephens became head of the Division's Pedology Section and was based in Adelaide, where he contributed to mapping the soils of South Australia. His book A Manual of Australian Soils went through three editions, and was a precursor to the Division's Handbook of Australian Soils, which amplified Stephens' concept of Great Soil Groups for Australia (Isbell 1996).

The general meeting of 19 April 1937, the first recorded for that year, heard J.W.C. Wyett talk on "Poisons, drugs and anaesthetics". John Wyett earned a Diploma in Pharmacy and a Bachelor of Science degree in Tasmania, and was later to gain some prominence for his courage and bravery in the Australian Army during the Second World War. He was present at the fall of Singapore and endured torture at the infamous Changi prison camp. He was later to write about his experiences, discussing frankly some of the inadequacies of the military leadership of the time (Wyett 1996).

\section{THE BIOLOGICAL SURVEY OF TASMANIA}

A meeting was held on 18 May 1937 at the home of J.W. Evans, at which the Club discussed and adopted a proposal to initiate a Biological Survey of Tasmania. The idea that there should be biological surveys for all of the Australian states, to begin to document the great biological diversity of this continent, had been mooted and discussed in preparation for the meeting of the Australian and New Zealand Association for the Advancement of Science that took place in Auckland, New Zealand, on 12-17 January 1937. Dr J. Pearson was the Tasmanian representative, and as a result of the May 1937 meeting that followed, the Tasmanian Biological Survey was launched with Dr Pearson as Chairman and Capt. D.C. Pearse as Secretary of the Committee. The project, which could be seen as an offshoot or adjunct to the Biological Club, flourished under Pearson's chairmanship during the years 1937 to 1940 . The history of the Tasmanian Biological Survey from its inception until its demise in 1983 was documented by Guiler (1996) and needs no elaboration here. The project involved many of the active members of the Biological Club.

\section{SOME FURTHER MEETINGS, 1938-1939}

The middle of 1937 marked the end of the first two years of the existence of the Biological Club. Members who had given talks in that initial period of 24 months now began a "second round" of presentations. In addition, other members made their appearance, some of whom retained a long association with the Club. Some members who spokeduring the following two years included Dr H.D. Gordon, an Edinburgh-trained botanist, who gave a talk (18 July 1938) on "Mycorrhiza", mainly dealing with the symbiotic relationship of fungi with the Ericaceae, especially of Rhododendron. Hugh Gordon later became the Honorary Secretary of the Biological Club, serving during 1944-1947, until such time when he left Tasmania to take up a Chair at a New Zealand university. Other speakers between July 1937 and the end of 1939 included J.F.N. Murray on pasture grasses (15 Aug. 1938), W.H. Clemes on climatic cycles, referring to geological evidence of the climate of various periods of geological time (19 Sept. 1938), G.K. Meldrum on liver fluke (20 June 1938), and S.W. Steane, on forests and fires (15 May 1939).

\section{SOURCE OF BIOLOGICAL CLUB MEMBERS}

The genesis of the Biological Club needs to be viewed in the context of the scientific community that was present in Hobart in the mid-1930s, as the members, never numbering more than 20 , were usually associated either with a government department (State or Commonwealth) or an educational institution (University of Tasmania, Tasmanian Education Department or a private school). Only rarely was a Club member drawn from private employment or practice.

Before the days of formal government departments in Tasmania, the appointment of W. Saville-Kent as Inspector of Tasmanian Fisheries in 1884 must be seen as an important step. The Tasmanian Government was keen at that time to develop both a salmon industry and an oyster industry on a sustainable basis, and recognised the need to manage fisheries if stocks were not to be depleted (Harrison 1997). Nevertheless, it was not until 1913, when a Select Committee, set up under the chairmanship of J.A. Lyons, later to become Prime Minister of Australia, recommended that a new government department be established to control the state's fisheries. Three years later, the foundation Professor of Biology at the University of Tasmania, T.T. Flynn, was appointed Royal Commissioner to examine. "Tasmanian fisheries" and strongly supported the Lyons Report. However, although a new Fisheries Act was passed in 1925 and the Sea Fisheries Board was founded with a mandate to manage and initiate development, it was not until 1934 that the State Government actively promoted commercial fishing based on a close relationship with the newly-formed CSIR (Harrison 1994). Thus, it was not until the mid-1930s that the main steps towards promoting scientific research in the fishing industry were taken. The scientists who undertook this research were part of the pool from which the membership of the Biological Club was drawn. 
There were regional boards in the various districts established to promote agriculture prior to the founding of the Department of Agriculture in 1898. Once the Department was established, it had officers involved with horticulture, soils and animal husbandry. Nevertheless, as with fisheries, a major boost to agricultural research had to wait until the creation and subsequent development of CSIR, which helped formalise and stimulate partnerships between State and Commonwealth researchers into agriculture. After fisheries and agriculture, the third major area of Tasmanian primary production was forestry, with a Forestry Department established in Tasmania in 1921. One of the first areas of scientific activity within that Department was the start of the production of forestry maps in 1922 (Elliott et al. 2008), a process necessary to determine the extent of Tasmania's forest resources and to estimate a sustainable annual yield from those forests. During the 1930 s, a major development was the introduction of aerial photography for forest surveys, greatly accelerating the description of the forest resource. As was the case with agriculture and fisheries, the cooperation between State and Commonwealth departments was essential to provide efficient use of the limited available funding allocated to research. This came about with the creation and development of CSIR, which not only placed emphasis on partnerships, but also provided bridges between researchers in the various states who might not otherwise have been in communication.

Although an Advisory Council of Science and Industry was formed in 1916 by the Government of Prime Minister Billy Hughes to establish an Institute of Science and Industry to undertake, review and disseminate results of scientific research, it was not given sufficient funding to develop and achieve its goals. In 1926, the Council for Scientific and Industrial Research (CSIR) was established with the aim to carry out scientific research to assist primary and secondary industries in Australia, namely, farming, mining and manufacture. During the $1930 \mathrm{~s}$ and $1940 \mathrm{~s}$, research included the fields of animal pests and diseases, the preservation of foodstuffs, and forest products. In 1949 , CSIR was renamed CSIRO and took on additional roles (Anon. 2008), but the formative years of its first two decades were important ones in shaping the nature of research in Tasmania, and it was during this period that the Biological Club was formed. In Tasmania, the CSIRO developed a Tasmanian Regional Laboratory, of which horticulturalist D. Martin became Officer-in-Charge, and which also employed other researchers, such as fisheries scientist A.G. Nicholls and soil scientist C.G. Stephens (see table 1). Cooperation with scientists in the Tasmanian government departments was made easier by the fact that the formation of partnerships between CSIRO researchers and those from other organisations was actively encouraged and promoted.

Other members of the Biological Club were associated with educational institutions. The University of Tasmania, founded in 1890 with the first Professor of Biology appointed in 1911, was the source of some of the Club's earliest members (Gordon, Hickman, McAulay). The school system, both public and private, was the source of several members (Brett, Clemes, Unwin), and private enterprise (Wyett) or private medical practice (Crowther) was a further source.

\section{WOMEN AND THE BIOLOGICAL CLUB}

The members of the Biological Club listed in table 1 were all men. That the Club should be an exclusively men's club was not written into the set of ground rules decided upon during its inaugural meeting on 6 June 1935 . No mention of any prohibition of women can be found amongst the written records that survive. We can ask the question whether women were excluded from joining because it might have been thought that they were incapable of becoming distinguished biologists. The answer to this appears to be emphatically in the negative. The Tasmanian Biological Survey, described earlier, readily sought the advice and expertise of women scientists in the pursuance of their goals. Table 2 lists six of these scientists, some of whom were resident in Hobart and some interstate. Correspondence between the Chairman of the Tasmanian Biological Survey and the individual scientists (archived in the Special and Rare Materials Collection, University of Tasmania, Morris Miller Library) shows the respect that the Survey had for the expertise of those scientists, whose contributions to the Survey were much appreciated. Therefore, the exclusion of women from membership in the Biological Club, or at least a de facto exclusion, cannot be attributed to any notions about the ability of the women to engage in scientific pursuits.

Women's universal suffrage was achieved in New Zealand in 1893 and in Australia in 1902, long before North America and Europe, and may be attributed to a concerted wave of feminism that occurred in the late nineteenth century. However, feminist sentiments were on the wane during the 1920 s and the Great Depression of the 1930s brought with it pressing economic concerns that became the major issue for most people. The second wave of feminism had to wait until the late $1960 \mathrm{~s}$, and focused on gaining equality with men in the workplace and in society. In Australia, male-only clubs were not uncommon in those times and public bars were restricted by convention, if not by law, to men until the late $1970 \mathrm{~s}$ when women's activism and anti-discrimination legislation resulted in change. Thus, the failure to invite a woman scientist to join the Biological Club can be seen as conforming to one of the unwritten social conventions of that era. It was not until Dr J.N. (June) Olley received an invitation in the late 1980 s from the Club's then Hon. Secretary, J.W.C. Wyett, that the door was open for the Biological Club to have women members.

\section{THE YEARS 1940 TO THE PRESENT}

The Biological Club has continued its existence almost uninterrupted from its inception in 1935 to the present time. A brief hiccup occurred in 1943, after Japan entered the Second World War, as the imposition of enforced blackouts in Hobart prevented the holding of evening meetings in member's homes. However, that restriction was short-lived and the Club has survived up to now with virtually the same set of ground rules with which the Club began. Minor changes have occurred such as the meeting day being changed from the third Monday of the month to the second Tuesday of the month. Emphasis is still placed on papers being of general interest that promote discussion, visiting presenters are encouraged and visitors to meetings are welcome. Spanning the decades, the Club has had amongst its membership some of the most distinguished members of Hobart's scientific 
TABLE 1

Names of members who gave talks during the period 1935-1939

\begin{tabular}{lll}
\hline Name & \multicolumn{1}{c}{ Affiliation } & Field of expertise or interest \\
\hline Brett, R. Gordon* & Tas. Dept of Education & Schoolmaster \\
Carne, Walter M.* & CSIR & Horticulturalist \\
Clemes, William H. & Clemes School & Schoolmaster \\
Crowther, William L.* & Private practice \& R.H.H. & Medical practitioner \\
Evans, John W.* & Tas. Dept of Agriculture & Entomologist \\
Gordon, Hugh D. & University of Tasmania & Botanist \\
Hickman, Vernon V.* & University of Tasmania & Invertebrate zoologist \\
Lewis, Arndell N.* & Private practice \& U. Tas. & Lawyer, geologist \\
Martin, Donald* & CSIR & Horticulturalist \\
McAulay, A. Leicester & University of Tasmania & Physicist \\
Meldrum, G. Keith & Tas. Dept of Agriculture & Veterinarian \\
Murray, John FN. & Govt \& private practice & Agricultural land valuer \\
Nicholls, Aubrey G. & CSIR & Fisheries scientist \\
Pearse, D. Colbron & Tas. Museum \& Art Gallery & Artist, designer \\
Pearson, Joseph* & Tas. Museum \& Art Gallery & Vertebrate zoologist \\
Raphael, Tom D.* & Tas. Dept of Agriculture & Horticulturalist \\
Steane, Samuel W. & Tas. Dept of Forestry & Forestry policy \\
Stephens, Charles G.* & CSIR & Soil scientist \\
Unwin, Emest E.* & The Friends School & Schoolmaster \\
Wyett, John W.C. & Private industry (Cadburys) & Businessman \\
\hline " & Thdictes a &
\end{tabular}

* indicates a founder member of the Club

TABLE 2

Some women scientists who participated in the Tasmanian Biological Survey

\begin{tabular}{lll}
\hline Name & \multicolumn{1}{c}{ Affiliation } & Field of expertise or interest \\
\hline Joyce Allan & Australian Museum, Sydney & Marine molluscs \\
Ellen Clark & National Museum, Victoria & Freshwater and land crayfish \\
Winifred Curtis & University of Tasmania, Hobart & Vascular flora of Tasmania \\
Valerie May & University of Sydney, N.S.W. & Freshwater and marine algae \\
Janet Somerville & Tas. Dept of Education, Hobart & Ferns, land leeches \\
Joyce Vickery & National Herbarium, N.S.W. & Grasses \\
\hline
\end{tabular}


community. The list of members, aside from people whose names have been mentioned earlier in this paper, includes academics such as H.N. Barber, I.R.C. Bick, E.A. Colhoun, E.R. Guiler, L.McLeod, R.M.McQuilkin, R.C.Menary, J.B. Reid, B.I.H. Scott, D.M. Stoddart and G.C. Wade, employees of Commonwealth and State Government departments such as T.M. Cunningham, I.D. Geard, J.M. Gilbert, K.D. Nicholls and P.G. Quilty, museum-based persons such as D.R. Gregg and N.J.B. Plomley, journalist M.S.R. Sharland, and medical practitioners such as N.M. Newman and J.S. Rogers.

\section{THE FUTURE}

The Biological Club celebrated its seventy-fifth anniversary with a dinner on 13 July 2010 attended by many past and present members and their partners. Membership in the Club is by invitation, with the maximum number of members at any time fixed at 20 . This limit is largely dictated by the fact that most meetings, as originally intended, are still held in the homes of members, thereby placing a practical constraint on numbers. One is entitled to ask the purpose of this littleknown Club. In the days of its founding, the 1930s, it was an avenue by which active scientists in the Hobart area could exchange information and discuss topics of mutual interest, as there were fewer alternative options for communication than today. The age structure of the members has changed considerably in the 75 years of the Club's history. Previously the entire membership was made up of active workers in the prime of their productive lives. It is now dominated by retirees. Nevertheless, with increasing calls by governments for physically able pensioners to remain productive and contribute to society and to the economy, the Biological Club provides an avenue by which retirees can learn about new developments from younger colleagues. It turn, it gives the younger members the opportunity to benefit from the experience and accumulated wisdom of their senior colleagues.

\section{REFERENCES}

Anon. 1937: Fruitgowing. Great Britain's Imports. Australia's contribution. Sydney Morning Herald, Sydney, 23 Sept. 1937, p. 9.

Anon. 1944: Obituary of Ernest Ewart Unwin, The Mercury, Hobart, 21 Sept. 1944, p. 4

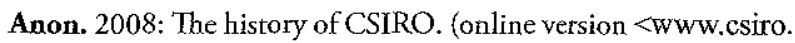
au/org/CSIROHistoryOverview $>$, viewed 8 August 2010).

Anon. 2010: Division of Denison (state). Wikipedia, the free encyclopedia._<en.wikipedia.org/wiki/Division_of_ Denison_(state)>, viewed 17 Sept. 2010.

Elliott, H.J., Felton, K.C., Jarman, S.J. \& Stone, M.G. 2008: A History of Innovation: Eighty-five years of research and development at Forestry Tasmania. Forestry Tasmania, Hobart, Australia: 392pp.

Fenton, J. 2004: A Century Afield. Tasmanian Field Naturalists Club, Hobart: $168 \mathrm{pp}$.

Guiler, E.R. 1996: Half a century before its time: the Tasmanian Biological Survey, 1936-83. Tasmanian Historical Research Association, Papers \& Proceedings 43: 149-153.

Guiler, E. 2006. Hickman, Vernon Victor (1894-1984). In Australian Dictionary of Biography, online Edition, updated continuously, ISSN 1833-7538. <www.adb.online.anu. edu.au/biogs/A170527b $>$, viewed 6 August 2010.

Harrison, A.J. 1994: Tasmanian Fisheries 1880-1990: Does better bait land more fish? <www.users.on.net/ ahvem/ Fisheries/Tasmania/Tasmania $>$, viewed 6 August 2010).

Harrison, A.J. 1997: Savant of the Australian Seas. Tasmanian Historical Research Association, Hobart: 173pp. (Online version, Second Edition, <www.users.on.net/ ahvem/ Fisheries/Identities/Savant $>$, viewed 6 August 2010)

Isbell, R.F. 1996: The Australian Soil Classification. CSIRO, Melbourne. 143pp.

Martin, D. 2004: A Tasmanian Life. Tasmanian Historical Research Association, Papers \& Proceedings 51: 57-60.

McCarthy, G.J., 2004: Evans, John William (1906-1990). In Encyclopedia of Australian Science, online version <www. eoas.info/biogs/P001888b>, viewed 8 August 2010.

Oats, W.N. 2006: Unwin, Ernest Ewart (1881-1994). In Australian Dictionary of Biography, online Edition, updated continuously, ISSN 1833-7538. <www.adb.online.anu. edu.au/biogs/A120340b>, viewed 8 August 2010.

Potts, B.M. \& Reid, J.B. 2003: Tasmania's eucalypts: their place in science. Papers and Proceedings of the Royal Society of Tasmania 137: 21-37.

Scott, B. 2006. McAulay, Alexander Leicester (1895-1969). In Australian Dictionary of Biography, online Edition, updated continuously, ISSN 1833-7538. <www.adb.online.anu. edu.au/biogs/A100702b>, viewed 8 August 2010.

von Oppela, C. A. 2006: Crowther, Sir William Edward Lodewyk Hamilton (1887-1981). In Australian Dictionary of Biography, online Edition, updated continuously, ISSN 1833-7538. <www.adb.online.anu.edu.au/biogs/ A170269b.htm $>$, viewed 8 August 2010.

Wyett, J. 1996: Staff Wallah: At the Fall of Singapore. Allen \& Unwin, St. Leonards, NSW: 225pp.

(accepted 5 October 2010) 